\title{
TOLLING - AN ALTERNATIVE SOURCE OF WORKING CAPITAL FINANCING
}

\author{
Kamila Janovská ${ }^{1}, \check{S}^{2}$ rka Vilamová ${ }^{2}$, Iveta Vozňáková $^{3}$, Jiří Staněk $^{4}$, \\ Petr Besta ${ }^{5}$ \\ ${ }^{1}$ Vysoká škola báňská-Technická univerzita Ostrava, Fakulta metalurgie a materiálového \\ inženýrství, 17. listopadu 15, 70833 Ostrava \\ Email:kamila.janovska@vsb.cz. \\ ${ }^{2}$ Vysoká škola báňská-Technická univerzita Ostrava, Fakulta metalurgie a materiálového \\ inženýrství, 17. listopadu 15, 70833 Ostrava \\ Email: sarka.vilamova@vsb.cz \\ ${ }^{3}$ Vysoká škola báňská-Technická univerzita Ostrava, Fakulta metalurgie a materiálového \\ inženýrství, 17. listopadu 15, 70833 Ostrava \\ Email: iveta.voznakova@vsb.cz \\ ${ }^{4}$ TOLFIN, s.r.o., Mostárenská 1140/48, 70602 Ostrava - Vitkovice \\ Email: jiri.stanek@tolfin.cz. \\ ${ }^{5}$ Vysoká škola bán̆ská-Technická univerzita Ostrava, Fakulta metalurgie a materiálového \\ inženýrství, 17. listopadu 15, 70833 Ostrava \\ Email:petr.besta@vsb.cz
}

\begin{abstract}
The tolling method can be considered as an effective tool to deal with critical situations of a company in the area of cash flow. Tolling can be characterized as a non-traditional tool of working capital financing that can be used in a project dealing with a critical situation of the company, primarily in order to finance production. Financing by means of the tolling method in the Czech Republic is primarily carried out on the basis of a private investor in small or medium-sized enterprises whose business activities are in the areas of civil engineering and light engineering. The article shows the potential utilization of tolling in construction industry and it points to the risks associated with inappropriate or poorly prepared application of the tolling method.
\end{abstract}

Keywords: construction industry, financial crisis, tolling, working capital financing.

JEL classification: G01, L74, M21

Doručeno redakci: 11.6.2012; Recenzováno: 9.4.2013; 5.4.2013; Schváleno k publikování: 11.9.2013

\section{Introduction}

The term financial crisis is very frequently used nowadays, and you can come across it several times a day in newspapers, in radio or television news, however, different users often understand the content of this expression in different (various) ways. You can also find various definitions of the financial crisis in scholar literature as well, often very different from one another. According to Laeven, Valencia (2012) a banking crisis is defined as systemic if two conditions are met:

1) Significant signs of financial distress in the banking system (as indicated by significant bank runs, losses in the banking system, and/or bank liquidations)

2) Significant banking policy intervention measures in response to significant losses in the banking system.

According to Musílek (2012) a financial crisis is defined as a significant deterioration in the vast majority of financial indicators, expressed by a lack of liquidity of the financial system, extensive financial insolvency of financial institutions, an increased volatility of yield rates of 
financial instruments, a significant decrease in the value of financial and non-financial assets and a significant reduction in the size and allocation of savings in the financial system. Mikušová (2012) sees the financial crisis in terms of the theory of chaos. From the view of the theory of chaos an economy is a system operating in conditions with a limited number of sources. Theories of chaos as well as a systematic approach bring a statement on the economy and its probable cyclic or chaotic behaviour.

The banking sector, which has currently been continuing in tightening the interest and noninterest conditions in many segments of the credit market thus slowing down the provision of loans, represents a crucial source of funding of Czech industrial enterprises. The enterprises must look for alternative financial resources in order to finance their current and future working capital needs, and the method of tooling is among them. The tolling method can be characterized as a method of effective working capital financing during which the funding body (tolling company) uses either its own free resources or, more often, complements these own resources using a bank credit so as to finance the needs of the manufacturer. Financing by means of the tolling method in the Czech Republic is primarily carried out on the basis of a private investor in small or medium-sized enterprises whose business activities are in the areas of civil engineering and light engineering.

\section{The financial crisis in the Czech Republic in 2007-2011}

Developed countries have been facing financial instability since August 2007, thanks to the globalization and the mutually interconnected character of financial markets, the financial crisis moved to Europe in 2008. The European Central Bank responded by using an expansionary monetary policy and by decreasing the interest rates. At the outbreak of the financial crisis, the Czech Republic was one of the more stable countries. The Czech National Bank also supported the market by supplying liquidity and by applying a more loose monetary policy. Given that the open Czech economy is heavily dependent on the global development, it was not able to avoid recession and a slump in its economic performance in 2009 (due to the fall in foreign demand). In 2010 the Czech economy still remained affected by structural dependencies that made it highly sensitive to the development of the business cycle abroad, and had an impact on its overall international competitiveness.

The economic environment in the second half of 2011 was hampered by further deepening of the Euro-zone debt crisis and by increasing concerns about its infiltration into the real economy, with a negative impact on the global growth ${ }^{1}$. The situation in the Czech Republic during the global crisis was following the problems of all other states. The world was facing a deep economic crisis and did not want to be involved in unnecessary spending. Consequently, the manufacturers in the CR got into troubles as well (the Czech industry is highly dependent on exports), especially the automotive industry, the glass industry and the construction industry.

\section{Banking sector in the Czech Republic}

According to Miklošík (2011) the economic situation has a direct impact phase on the business cycle and subsequently reflects the addition of other events in other areas in the landscape. The financial sector (both world and Czech one) is marked by scepticism and liquidity preference, reflected both in the interbank market and in the restrictive credit policy of banks. The banking market of the CR is almost exclusively in the hands of foreign banks, and some of them have been very severely affected by the crisis and therefore their strategic

\footnotetext{
${ }^{1}$ statistiky MPO - Analýza vývoje ekonomiky a konkurenceschopnosti ČR za 3. čtvrtletí 2011, [online], [cit. 2012-5-30] dostupné z http://www.mpo.cz/
} 
plans and tools to ease down the impact of the crisis are also applied in their Czech affiliates. The result is a decrease of interest rates by the central bank and other operations aimed at raising finances in the economy.

The global economic crisis and the related uncertainty force banks to withhold the financial means, resulting in their lower availability for other subjects. The financial sector in the CR maintains its conservative approach to credits, which leads to a price increase of loans, which dramatically reduces the volume of loans provided. The banking sectors represents a crucial source of financing of Czech firms, which have recently been going through an extremely difficult and unstable period, characterized by a more cautious credit policy of the financial institutions, when the banks request all clients, without exception, to meet all the conditions for granting a loan, including a quality security instrument. The Czech banking sector continues to tighten the interest and non-interest conditions in many segments of the credit market, thus reducing the tempo of granting credits.

Securing working capital financing of companies is, in many cases, very difficult and it can be stated that the problem of raising resources for working capital financing is mainly concentrated in small and medium-sized companies. Stricter rules for granting loans (higher interest rates and faster redemption, higher demands for guarantees and credit security) are negatively affecting especially small and medium-sized enterprises, and, given that the banking market is largely monopolized, a transition to another bank is usually very complicated.

For the above presented reasons, especially small and medium-sized companies have to look for alternative sources of financing their current and future working capital needs, which can certainly include the tolling method.

\section{Tolling}

According to Staněk (2011) tolling is an economic and business system of financing shortterm assets, in which the submitter lets the processor to be in charge of manufacturing the final products, using their own raw materials. According to currently available information, the utilization of the tolling instruments is primarily related to the project of VÍTKOVICE OSINEK. Tolling was used by Osinek Company entirely owned by the state (however, it was not a case of public support; everything was strictly conducted on commercial basis). Osinek Company was purchasing raw materials, materials and energies on its own account and it had metallurgical products manufactured by VÍTKOVICE STEEL, a.s. using the purchased raw materials and materials, along with consumption of the supplied energy media. The company paid for processing commission for the manufactured products. The finished steel products were sold by the company to customers. In connection with the delivery of products, OSINEK Company also provided resources to cover the cost of sales related to product delivery.

It is also possible to find some information on funding of SETUZA, a.s. company from Ústí using tolling. A certain form of tolling has been applied by commercial enterprises in the Russian Federation and Ukraine, but in these cases, it was primarily focused on securing the input commodities and subsequent withdrawal of production, but without an elaborate system of processing commission, accounting, etc. According to Avdasheva (2002) it was a modified type of barter exchange transaction. According to Birch (2002) the Australian taxation laws define tolling as a certain form of consortium, where the consortium members participate on the output of a company in which the tolling is implemented in proportion to their capital participation. There is virtually no information at all about tolling in the scholar literature. 
The tolling method can be characterized as an effective method of working capital financing, in which the funding subject (the tolling company) uses either its own free resources or, more often, complements its own resources using a bank credit to finance the needs of the processor. A specific feature of tolling financing is that the short-term assets, taken from the tolling resources, are at all times and in all forms (raw materials, work in progress, receivables) owned by the tolling company providing the funds, not by the processor. If one of the sources of financing is a bank loan, the debtor is not the processor, but, again, the tolling company. The issue of tolling is reflected in several areas of human activity, including the economic, financial, legal, and, last but not least, political sphere.

According to Staněk (2011) tolling can thus be characterized as a non-traditional tool of working capital financing that can be used in a project dealing with a critical situation of the company, primarily in order to finance production. According to Štěpán (2009) this classification of tooling as a non-standard financial instrument is also included in a research project of Marek covering the period of 2005-2011, named "The Development of Financial and Accounting Theory and Its Applications from an Interdisciplinary Perspective."

In cases where a manufacturer operates using the form of orders or projects, it is not always necessary to provide capital for the entire production of the processor, but only for specific projects. Such a subject usually uses normal banking products and, at the same time, a modified method of tolling - project financing in order to help the company finance some specific projects.

The funded subject (processor) can be characterized as a subject in financial problems which does not have sufficient resources to finance the production and sales, i.e. to cover the net working capital, but despite the financial difficulties, it is in possession of a profitable product, well-mastered technology of production, stable sales possibilities and sufficient portfolio of customers paying their liabilities. Their financial problems can be considered as temporary, they are not deepened by the emergence of new production and sales losses and there is a way to overcome the financial difficulties through implementation of the restructuring program.

The funding body (tolling provider - submitter) is an entrepreneurial organization, not a bank, that has another (different) method of entrepreneurial activity. This entity is characterized by the fact that it has its own resources which the organization is willing to use, within the frame of its business intent, for financing production and sales of the funded subject or it is able to draw other resources in the form of a bank loan. The activity of the funding subject is based on the assumption that the financial problems of the funded subject are of temporary character and they will be resolved during the tolling financing and the subject will be able to secede from the tolling relationship. The scheme of the basic links is presented in the following Fig. 1. Note to Fig. 1: the source of financing does not have to be a bank only; it can be another external source as well. 
Figure 1: Tolling financing system

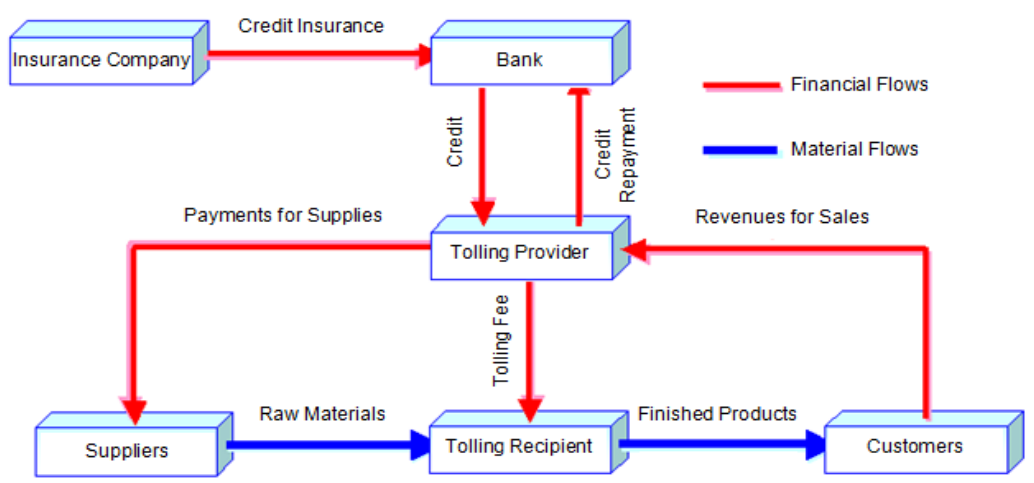

Source: Stanek, J., Lenort, R., Samolejova, A. 2011. Prerequisites for metallurgical company's working capital effective financing through tolling agreement, METAL 2011, pp. 1144-1149, ISBN 978-80-87294-17-8

According to Staněk (2011), there are certain principles and assumptions for the implementation of tolling which define a sequence of steps, some of which must be taken before starting the actual implementation and tolling. These activities can be arranged in the following way:

1) Inquiry

2) Principles and their observance

3) Implementation prerequisites and their fulfilment

4) Financial analysis as a basis for decision-making

5) Financial plan

6) Initialization of implementation

7) Actual realization of financing

Stages 1 to 5 are very demanding, both in terms of administration and in terms of subject and time. Given that these stages require capacity and labour workload, especially from the submitter, it is appropriate to sign a contract with the subject applying for financing using the tooling method at the beginning of the negotiations, which will define the individual steps of mutual cooperation and which will define the commission of the submitter for the performed operations, even if tolling will not be implemented.

\section{Problematic areas of tolling}

Basic prerequisites of implementation of tooling

During the 3rd stage, the submitter presents the principles of the implementation of tolling, defining the basic prerequisites deciding whether it is possible to implement tolling, within the scope of financing, for the tooling applicant. The principles include in particular:

- examination of the legal entity from the point of view of the valid legislation (to determine whether the entity applying for funding using the tolling method really wants to solve their financial situation and whether it is not only an attempt to secure financial resources by means of a procedure that may be on the edge of criminal liability),

- examination of the legal entity in terms of its manufacturing base (to determine whether the means of production are owned by the entity applying for funding using the tolling method, or whether they are not leased and, in case they exist as a collateral instrument, to see if there is no danger of their removal or restriction of operation),

- examination of the entity applying for funding using the tolling method from the perspective of the product (to determine whether the entity applying for funding using 
the tolling method has a product that is saleable on the market and whether the production of such product is profitable),

- examination of the entity, whether it is willing to provide all the information about its activities and whether it is willing to allow the tooling provider to take part in the controlling bodies of the company or even in the managing bodies of the company.

According to Staněk (2011) the applicant for tolling should meet the above described principles without any conditions. If there are any doubts as far as their fulfilment is concerned, it is very risky to implement tolling in the organization of the applicant. This stage is often very administratively and time consuming, especially depending on the size and complexity of the organizational structure of the applicant.

\section{Financial analysis}

According to Staněk (2011) the greatest attention should be paid to the fourth stage, since the results of the performed financial analysis allow the funding subject (submitter) to obtain detailed information on the financial health of the applicant's company. In a broader sense, the financial analysis focuses on the future as well, especially on the prediction of financial distress, the risk of takeover by a foreign corporation, on the expected future valuation of the company.

Given the seriousness of the decision, the financial analysis and the evaluation of its outcomes must be based not only on official documents (the basic account sheets - the balance sheet, the profit and loss account, the statement of cash flow, annual reports, auditor's reports, etc.), but also on documents that are not commonly provided - information from financial and management accounting, internal records, calculations. The performed financial analysis and its outcomes should identify strong and weak points of the economy of the evaluated company, and it should also serve as a basis for the financial management, planning and forecasting.

\section{Compiling the Cash Flow}

The output of the fifth stage is a financial plan that is based on partial plans of activities of the processors and is converted into value terms. The partial plans may include the plan of sales, the purchase plan, the plan of human resources, the production plan, the plan of repairs and maintenance of assets, the plan of investments in the expansion, or the renewal or modernization of the assets. The financial plan is an integrating plan of the company, because all the activities (partial plans) are ultimately reflected in the financial means. Information on the production plan, the cost plan, the plan of human resources, but also on other parts of the company plan should be given by the tolling applicant to the tolling provider which should subject them to a critical analysis. However, the preparation of the financial projection of tolling financing is fully within the competences of the tooling provider (obviously using the documents of the applicant). This step is absolutely necessary to take before the tolling launch, since this financial projection will provide vital information on the amount of required resources and their time distribution.

In the familiar cases of application of tolling in the CR up to now, the preparation of Cash Flow tooling projection at weekly intervals has acquitted itself well, while the total length of the planning period should be at least long enough to stabilize the amount of the necessary financial resources or to see them decline. During the processing of the Cash Flow tooling projection, it is necessary to count not only with regular payments and collection, but also with those fluctuations and modifications that can be predicted (seasonal demand for products 
and the need to increase stocks of finished goods without encashment for some time, the need for stockpiling before the planned shutdown of equipment of the supplier, etc.). The initial period of implementation of tolling often reveals certain distrust of suppliers towards the new partner (the provider of tolling) and they may require advance payments. The need for external funds to finance the working capital calculated using this method is an important information for the tolling provider, but it should be gradually refined after the conclusion of contracts with the suppliers and customers, and corrected taking into account the newly agreed terms of repayment, both at the input and output side, as well as to account the creditworthiness and payment behaviour of the customers etc.

Preparation of the financial projections of the processors, whose income comes primarily from the processing commission (or fees from the mandate contract, the trade agency contract), which are used to pay the wages, compulsory deductions, purchase of indirect material and other items, is an evident prerequisite. The Cash Flow plan should be made available to the submitter by the processor, as an evidence of "feasibility" of the tolling intention, proving that the processor will be able to pay the processing of material input performed by the submitter from the tooling commission, and will be able to complete production of the final product.

\section{Accounting administration}

According to Staněk (2011) the financing starts (6th stage) only when the contractual documentation forming the legislative framework (especially the trade agency contract, the framework agreement, the mandate contract and a number of general contractual provisions) is completed and is confirmed by the participating parties. The commencement of the financing is very important for both subjects, not only because of the transfer of funds, but primarily because from that moment it is necessary to keep detailed records of all financial transactions in the accounting documents, so as not to have any doubts in the future about how these operations were carried out. Keeping records of the tolling operations in the accounting documents of the processor must be realized in such way so as to resemble as closely as possible the situation in which the processor does not need financing using tolling, i.e. costs, revenues, assets, liabilities and economic results must be recorded as the sum, together with the submitter's company. In case of restricted tolling, the bookkeeping is more complicated, because it is necessary to keep the same structure into organizational units in the submitter's accounting, which is identical to the processor's one. In this case, it is very suitable to use the same marking of the centre structure and joint accounts (numerical marking of synthetic and analytical accounts).

Accounting and financing prerequisites:

- the funding company depicts the production process along the line of consumption of the financed costs in all its stages, i.e. from the material in stock, through work in progress and semi-finished products, to finished products,

- the funding company has the groundwork for invoicing the delivered products to a customer,

- the funded company depicts the manufacturing process along the line of its additional costs in the same structure of the production stages, from work in progress, through semi-finished products, to finished products,

- the funded company covers its costs using the revenues from the processing commission invoiced from the funding company,

- provided that there is a reliance of the funding company upon the funded one, the accounting operations in the books of the financing company can be performed in 
cooperation with accounting fellow-workers of the funded company, especially in manufacturing accounting (material consumption, accounting of work in progress, semi-finished products handovers, realization costs of finished products, overhead costs allocation, if the funding company includes these in its costs, etc.)

- the funding company keeps the analytical record of assets and liabilities,

- accounting of financial transactions is expected to be carried out directly by the employees of the financing company (accounting of payments of liabilities, allocation of debt collections, etc.),

- the funding company must be able to administer the current account at a bank, to make payment orders for liabilities, operate the communication system with a bank where the current account is open,

- the financing company is in charge of its payroll accounting for its own employees or it has it done externally,

- it is possible to perform stocktaking of assets of the funding company, especially with regard to inventories administered by the funded company,

- observing the same principles for the valuation of material stocks, valuation of stocks of its own production, using the exchange rate of foreign currencies goes without saying.

All accounting transactions must be conducted according to Act No. 563/1991 of the Code, which determines the extent and method of the accounting procedures. The basic precondition of proper accounting administration of tolling transactions is mutual cooperation of the employees of both companies and the mutual exchange of information from the accounts.

\section{Security instruments}

In case of the implementation of the tolling method, the issue of security instruments is particularly important, because in many cases, it is the limiting factor deciding whether the application of tolling is possible at all. The fact that the submitter procures the input commodities and is their owner throughout the entire production cycle may create the impression that the title of ownership to the procured input materials is sufficient and there is no need to ensure any further security for the financial resources allocated to the system. There are numerous instruments that can be used to provide security for the financial resources used for the implementation of tolling, and in essence, they use virtually identical instruments that are used by the financial (banking) sector. The bills co-accepted by the company owners or security using the company assets, including the certificate of registration into the real estate cadastre or into the security register, seem to be the most suitable options.

\section{Potential utilization of tolling in construction industry}

The situation in the construction industry in 2007 - 2013

Construction industry is, without any doubts, one of the main indicators of economic growth of the country. Despite the drastic impact of the global financial crisis on the demand for building production, construction industry is still an important sector of the economy, accounting for approximately $9 \%$ of the employment in the economy and for 6-7\% of the GDP.

In 2008, the construction production showed an annual increase by $0.6 \%$. The impacts of the global financial crisis affected especially structural engineering (down by 6.6\%), while civil engineering driven by the state orders was increasing throughout the year (the annual growth by $11.8 \%$ ). Small companies showed better abilities to cope with the unfavourable 
development, as they maintained higher growth of production in comparison with larger companies thanks to their flexibility.

In 2009, the annual building production dropped only by $1.0 \%$. The entire year 2009 was characterized by a decline of structural engineering, going hand in hand with growth in civil engineering. However, there was a significant decrease of the volume of building contracts, particularly those financed from private sources.

In 2010, the construction industry was facing the delayed effects of the global economic crisis. The building production witnessed an annual slump by $7.8 \%$ in the first half of 2010 ; the year-to-year building production fell by as much as $12.2 \%$. In housing construction, the number of completed flats was almost at the same level as in the same period in the previous year, but there was a sharp decrease in the number of newly started constructions. According to Šulc (2011) January 2010 was, in terms of volume of granted mortgages, the worst month for the whole period of monitoring of the so called FINCENTRUM HYPOINDEX. According to this indicator, the volume of mortgages granted in January reached the amount of mere CZK 4.3 billion, while January 2009, with a volume of CZK 4.6 billion, was considered to be catastrophic.

In 2011, the building production dropped significantly, the decline had impact especially on civil engineering $(-14.6 \%)$ which was affected by the austerity measures of the government. Construction industry also faced weak demand of companies and households because of persisting uncertainty about the future development ${ }^{2}$.

According to Šulc (2011) the negative impact was also felt by the comparable basis, which includes massive completion of photovoltaic power plants in 2010. A survey conducted by CEEC Research company and by KPMG Czech Republic among building companies in the Czech Republic and Slovakia shows that a vast majority of directors of these companies expect that the year 2012 will be another year of crisis of the Czech construction industry and the return to growth is not expected in 2013 either. An average prediction of company directors involved in civil engineering or structural engineering shows the decline of the sector by $8.7 \%$ in 2012 and by further $1.1 \%$ in 2013 .

Czech building companies with more than 50 employees concluded new contracts for 33,720 building orders in 2009, which is more than in 2008, but the annual volume (total value) of these orders decreased by $26.4 \%$ to the total of CZK 183.6 billion. In the middle of 2010 , these building companies signed contracts for 10.6 thousand building orders worth CZK158.3 billion. Compared to the same period in 2009 , there was a decline in the value of concluded orders by about $20 \%$. The average value of a single order fell to CZK 5.4 million, which is a decrease of approximately $31 \%$. Another alarming decline in production in the sector continued in the second half of 2010 and in 2011. It also seems that the decrease in production of this sector has not reached its bottom yet ${ }^{3}$.

There was a significant decrease in the number of public orders in the described period, having more than $50 \%$ share on the total building production. In the1st half of 2010, the total value of awarded public orders decreased by more than $43 \%$, compared to the same period in 2009, while the decline in awarded public orders in the sphere of transport infrastructure,

\footnotetext{
${ }^{2}$ statistiky MPO - Analýza vývoje ekonomiky a konkurenceschopnosti ČR za 3. čtvrtletí 2011, [online], [vid. 2012-5-30] dostupné z http://www.mpo.cz/

${ }^{3}$ Časopis stavebnictví [online]. [vid. 2012-4-5]. Dostupné z:http://www.casopisstavebnictvi.cz/
} 
which amounted to $74.7 \%$, can be considered as very critical. After this period, the dramatic fall of production in the construction industry continued, particularly in public orders which play a crucial role especially in transport infrastructure construction and in the entire civil engineering area. Due to the impacts of the financial crisis, government austerity measures and a lack of funds, we cannot expect any increase in the demand from the private sector and the inhabitants either ${ }^{3 .}$

The above presented data show that the building sector has become a highly competitive environment (public orders are cancelled or suspended, large construction orders are not underway), which witnesses the beginning of competition between large building companies and small ones, eventually medium-sized building companies that has so far operated mostly in a certain region (area), where they usually had a stable market position.

As a result of the above mentioned facts, a large number of Czech building companies (mostly small and medium-sized firms) find themselves in a difficult financial situation - they must quickly respond to the changing market conditions, which include long maturity of receivables, stricter rules to acquire a bank loan and short maturity of liabilities. The situation of companies engaged in the construction industry, as outlined above, becomes very problematic and is, among other aspects, characterized by a significant lack of available financial means.

\section{Tolling combined with project financing}

In the Czech Republic, the tooling method was used in greater time and material scope in the project of VÍTKOVICE - OSINEK, when tolling as a way of working capital financing was realized in 2000-2005. The financing of the metallurgical part of VÍTKOVICE, a.s. company took advantage of the so called restricted tolling - this is financing of the entire scope of production and its sales. The mechanical engineering production used the so called project financing - financing of pre-defined projects. The application of tooling in mechanical engineering production required a specific approach to the individual projects - business cases. Project financing was therefore focused on the business case precisely defined by the contract with the customer, as far as the subject performance, delivery terms, payment terms, guarantees, etc. are concerned.

As mentioned above, the situation of companies engaged in the construction industry is characterized by a significant lack of available financial means. In order to finance the working capital of small or medium-sized companies, whose business activities are focused on the building sphere, the method of tooling can be combined with the project financing.

Tolling in the construction industry could be characterized as follows, according to Štěpán (2009):

- the submitter has the order (the building project) prepared by the processor, using a contract for work related to the selected contract,

- the submitter takes the advantage of the processor's purchasing department employees to purchase the material inputs required to perform the work and charges their consumption in the work in progress made to order, which the submitter opens for production of the given work,

- the processor receives an advance payment from the submitter for the delivery of the work and the employees of the processor themselves organize the purchase of the necessary inputs to produce the work, or to manufacture their own semi-finished products (castings, 
forgings, mouldings) and include them, together with the processing costs, into work in progress,

- due to the fact that the building orders are characterized by relatively long processing time (one-year long periods are not exceptional), the processor continually issues invoices for the individual stages of the work to the submitter,

- the submitter includes the ongoing invoiced stages of the work in their stocks of work in progress, thus becoming the owner of the goods in process, and the submitter keeps the records of orders; invoices for work in progress stages are paid to the processor,

- the submitter allocates the cost of bank interest in the work in progress

- after the completion of the work and its acceptance by the customer, the submitter issues the invoice to the customer including the contractual price,

- the processor accounts for the so called processing commission to the submitter, which represents the difference between the revenues from the given order and the cost of this order continuously accounted by the processor, allocated interests and also a reasonable share of the cost of submitter's administration.

The processing commission covering the processing costs and the economic result of the processor could be calculated according to the individual orders, taking advantage of the following formula, according to Štěpán (2009):

1. REVENUES (PRICE OF ORDER)

2. - COSTS of submitter divided into:

- direct material

- external transportations of direct character

- direct services

- interests from a loan allocated to the order

- overhead costs allocated to the order

- profit margin of the submitter

3. $=$ PROCESSING COMMISSION of the processor

In case of tolling combined with project financing, the submitter charges on order open for the given project, taking into account both the unit cost of materials and services related to the given contract, including the services of the processor and, at the same time, the overhead costs of the submitter which are allocated according to a predetermined schedule key.

\section{Conclusion}

The tolling method can be considered as an effective tool to deal with critical situations of a company in the area of cash flow, but it is also necessary to take into account the risks associated with inappropriate or poorly prepared application of the tolling method. The tooling method can be characterized as a method of effective financing of working capital, in which the funding subject (a tolling company) uses either their own free resources for financing the manufacturer's needs or, which is more common, their own resources are supplemented by a bank loan. A specific feature of tolling financing is the fact that the shortterm assets acquired from the tolling resources are at all times and in all forms (raw materials, work in progress, receivables) owned by the financing tolling company, not by the manufacturer. The advantage of this method of financing can also be seen in the fact that the form of tolling is not unchangeable, but there are possibilities to modify the method for each specific case of realization, of course, while respecting the fundamental economic, legal and also ethical rules. Deeper understanding of all the opportunities and risks associated with tolling financing of short-term assets may significantly contribute to more widespread 
utilization of this method in practice. At present, financing of working capital by means of the tolling method in the Czech Republic is realized mainly on the basis of a private investor in small, respectively medium-sized companies, whose business activities are focused on construction industry, and light engineering, especially in the form of tolling combined with project financing.

\section{Acknowledgement}

The work was supported by the specific university research of Ministry of Education, Youth and Sports of the Czech Republic No. SP2012/12 „Optimalizace tollingového projektu s využitím metod sítové analýzy”.

\section{References}

[1] AVDASHEVA, S., 2002. Tolling Arrangements in the Russian Industries: An Institutional Perspective. Journal of Economics and Business, East-West University of Thessaly, No 2, pp. 217-240, ISSN 0148-6195.

[2] BIRCH, CH., 2002.Tolling Companies and their income Taxation Features. Journal of Australian taxation, Vol. 5, No 2, pp.213-262, ISSN 1440-0405.

[3] LAEVEN, L. and F. VALENCIA, 2012. Systemic Banking Crises Database: An Update. IMF Working Paper 12/163, [online], [vid. 1.6.2012], dostupné z http://www.imf.org/external/pubs/cat/longres.aspx?sk=26015.0.

[4] MIKLOŠÍK, A., 2011. The impact of the economic cycle changes on the individual subjects' behaviour with the application to the advertising. In Crisis situations in the CzechoSlovak context after 1989. Prague: Central European Centre for Mission Studies.pp. 97-107.

[5] MIKUŠOVÁ, M., 2012. Crisis management. Review of interdisciplinary approaches to crisis and crisis management. Saarbrucken: LAP Publishing. ISBN 978-3-8473-4870-2 .

[6] MUSÍLEK, P. Analýza př́íčin a důsledků české finanční krize v 90. letech, výzkumná studie GAČR 402/02/1308 [online], [vid. 21.5.2012], dostupné $\mathrm{Z}$ http://nb.vse.cz/kbp/TEXT/Grant_krize_1a.pdf

[7] STANĚK, J., 2011. Předpoklady efektivního financování pracovního kapitálu metodou tollingu, disertační práce, FMMI, VŠB-TU Ostrava

[8] ŠTĚPÁN, J., 2009. Tolling - netradiční způsob financování podniku, bakalářská práce, Vysoká škola ekonomická v Praze

[9] ŠULC, J., 2012. Vliv krize na poskytování bankovních produktů v ČR, diplomová práce, FMMI, VŠB-U Ostrava 